International Journal of Life Sciences
Available online at www.sciencescholar.us
Vol. 4 No. 1, April 2020, pages: $50-57$
e-ISSN: 2550-6986, p-ISSN: $2550-6994$
https://doi.org/10.29332/ijls.v4n1.380

\title{
Consumption, Nutrient Digestibility and Nitrogen Retention in Pe Goats Received Ransum with Various Levels of Gamal (Gliricidiasepium) Balance Versus Concentrate
}

\author{
(1) \\ Muh. Sofyan a, I Gusti Lanang Oka Cakra b, I Gusti Agung Arta Putra c \\ Manuscript submitted: 09 November 2019 Manuscript revised: 18 December 2019, Accepted for publication: 30 January 2020
}

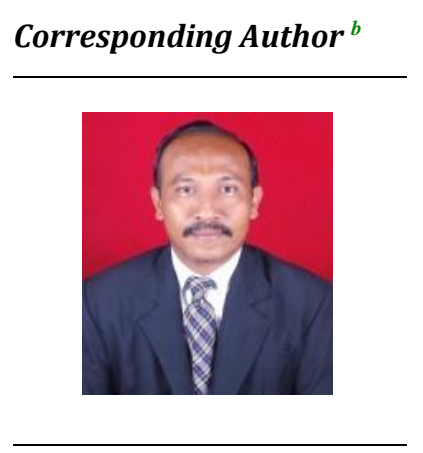

Keywords

concentrate; consumption; gamal (gliricidiasepium); nitrogen retention; nutrient digestion;

\begin{abstract}
The research aims to determine the consumption, nutrient digestibility and nitrogen retention in PE goats, which has been carried out in Sidemen Village, Karangasem, Bali and in the Lab. Animal Nutrition and Feed at Udayana University. The research design used was the Latin Square Design (LSD) with treatment consisting of (P1) 55\% field grass with 45\% concentrate; (P2) 55\% field grass with 15\% Gamal and 30\% concentrate; (P3) 55\% field grass with $30 \%$ Gamal and 15\% concentrate; (P4) 55\% field grass with $45 \%$ Gamal. Research variables include consumption, nutrient digestibility and nitrogen retention. The results showed the consumption of dry matter and crude protein between treatments was not significantly different $(P>0.05)$. Crude fiber consumption of $\mathrm{P} 4$ treatment was significantly $(\mathrm{P}<0.05)$ higher than $\mathrm{P} 1$, but $\mathrm{P} 4$ was not significant $(\mathrm{P}>0.05)$ higher than $\mathrm{P} 2$ and $\mathrm{P} 3$. The dry matter digestibility coefficient and crude fiber digestibility coefficient between treatments were statistically significantly different $(P>0.05)$. The digestibility coefficient of organic matter, crude protein digestion coefficient and nitrogen retention in the P1 treatment were not significantly $(\mathrm{P}>0.05)$ higher than $\mathrm{P} 2$, but $\mathrm{P} 1$ was significantly $(\mathrm{P}<0.05)$ higher than $\mathrm{P} 3$ and $\mathrm{P} 4$. The conclusion of this study is that the feeding of P2 treatment with a balance of $30 \%$ concentrate and $15 \%$ Gamal in the grass-based field feed is very efficient to increase consumption, nutrient digestibility and nitrogen retention in PE goats.
\end{abstract}

International Journal of Life Sciences (C) 2020.

This is an open access article under the CC BY-NC-ND license

(https://creativecommons.org/licenses/by-nc-nd/4.0/).

a Udayana University, Denpasar, Indonesia

b Udayana University, Denpasar, Indonesia

c Udayana University, Denpasar, Indonesia 


\section{Contents}

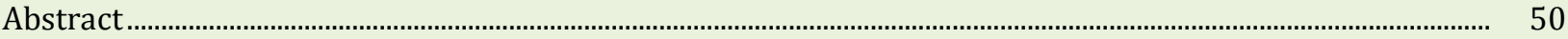

1 Introduction ................................................................................................................................................... 51

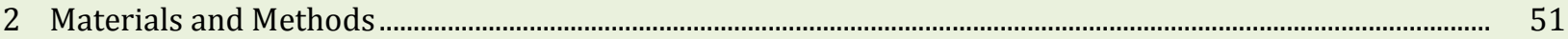

3 Results and Discussions ............................................................................................................................................ 53

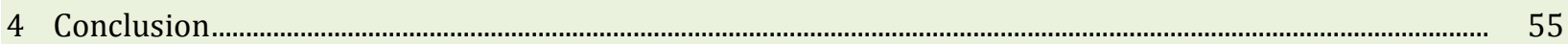

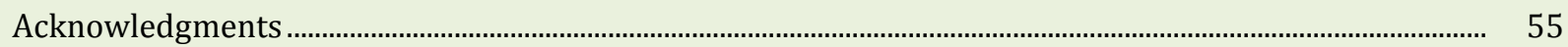

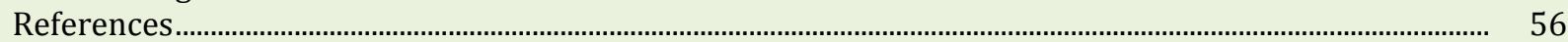

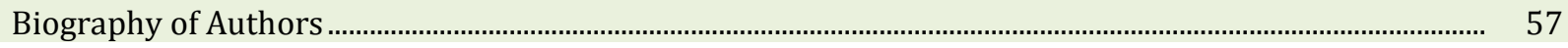

\section{Introduction}

Quality feed is the main indicator that determines the development of the livestock business. Habits of people who only rely on field grass as animal feed are not optimal in increasing livestock productivity due to lack of nutrient content infield grass. Jalaludin (1994), states that the crude protein content infield grass is 8-9\%, while TDN is $10-54 \%$. This situation is not very supportive of increasing goat productivity if only relying on field grass, so it is necessary to have an alternative to combine with the provision of Gamal (Gliricidiasepium) and concentrate. Sukanten et al. (1994), state that Gamal (Gliricidiasepium) contains a high protein of 23.5\% so that it is quite good given to livestock. It was further explained that Gamal (Gliricidiasepium) had a crude protein content of $20-30 \%$ dry ingredients, crude fiber $15 \%$, and in vitro digestibility of dry matter $60-65 \%$. According to Hartadi et al. (1980), concentrate plays a role in supplementing nutrient deficiencies from forages and containing less than $18 \%$ crude fiber, TDN more than $60 \%$. The combination of Gamal (Gliricidiasepium) and concentrate can cover the nutrient deficiencies of each feed material which ultimately can meet the needs for basic living, growth, production and reproduction. Based on this, a study was conducted to determine consumption, nutrient digestibility and nitrogen retention in PE goats that receive ransum with various levels of Gamal (Gliricidiasepium) balance versus concentrates.

\section{Materials and Methods}

\section{Research design}

The study design uses a Latin Square Design (BSL). The treatment consisted of P1 (55\% field grass with $45 \%$ concentrate); P2 (55\% field grass with 15\% Gamal and 30\% concentrate); P3 (55\% field grass with 30\% Gamal and 15\% concentrate); P4 (55\% field grass with 45\% Gamal).

\section{Place and time of research}

The research was conducted in Sidemen Village, Karangasem, Bali and in the Lab. Nutrition and Animal Feed at Udayana University for 3 months.

\section{Variable observed \\ Consumption of nutrients}

Calculation of consumption of dry ingredients per day (consumption of dry matter/day) (g BK) and nutrient consumption using the formula:

Consumption of dry matter (g/day) $=\sum$ consumption of feed $\mathrm{x} \%$ of feed dry matter

Nutrient consumption $(\mathrm{g} /$ day) $=$ consumption of dry matter/day (g BK) $x$ nutrient content of ransum (\% BK)

Sofyan, M., Cakra, I. G. L. O., \& Putra, I. G. A. A. (2020). Consumption, nutrient digestibility and nitrogen retention in pe goats received ransum with various levels of gamal (gliricidiasepium) balance versus concentrate. International Journal of Life Sciences, 4(1), 50-57. https://doi.org/10.29332/ijls.v4n1.380 


\section{Nutrient digestion}

The determination of digestibility is done by the total collection method. Stool samples were taken as much as $200 \mathrm{~g}$ for drying, then weighed again and taken as much as $10 \%$ of the dry weight of air to be mashed and carried out the proximate analysis.

Nutrient digestibility coefficient $=\frac{\text { nutrients consumed }- \text { nutrients in the stool }}{\text { nutrients consumed }} \times 100 \%$

\section{Nitrogen Retention (RN)}

The urine sample is taken as much as $100 \mathrm{ml}$ and immediately drops $75 \%$ HCL solution as much as $2 \%(\mathrm{v} / \mathrm{v}$ ) of the sample volume aims to bind $\mathrm{N}$, then analyzed in a laboratory to determine levels of $\mathrm{N}$.

Nitrogen retention $=$ consumed nitrogen $-($ feces nitrogen + urine nitrogen $)$

\section{Livestock and research cages}

The study used 4 goats with PE range of \pm 2 years with an average initial body weight of $40 \mathrm{~kg}$. Individual cages each measuring length, width, height $(150 \mathrm{~cm}, 100 \mathrm{~cm}, 125 \mathrm{~cm})$ and height $70 \mathrm{~cm}$ from the ground. Cage floor is made of small blocks with a distance of $2 \mathrm{~cm}$ and the roof of the cage uses asbestos. The rectangular feedlot is located in front of the goat. The drinking water container uses a 5 -liter volume bucket.

\section{Ransum and drinking water}

The ransum was composed of concentrates, Gamal (Gliricidiasepium) and field grass. Field grass and Gamal (Gliricidiasepium) were obtained from the rice fields around the research site. The concentrates arranged according to the composition of food substances according to the recommendation of Kearl (1982) are presented in table 1.

Table 1

Composition of concentrated ingredients and nutrient content of feed

\begin{tabular}{lccc}
\hline Material Composition (\%) & Concentrated & & \\
\hline Cornmeal & 30 & & \\
Molasses & 5 & & \\
Rice Bran & 20 & & \\
Soybeans & 15 & & \\
CaCO3 (Chalk) & 1.8 & & \\
Urea & 1.8 & & \\
Salt & 1.2 & & \\
Pignox & 0.2 & & \\
Wheat Bran & 25 & Field grass \\
Total & 100 & 82.6 & 2.7 \\
Nutrient Content (\%) & 86.5 & 5.9 \\
\hline Dry ingredients & 25.2 & 3.3 & 25.1 \\
Organic Ingredients & 15.9 & 18.9 & 27.4 \\
Coarse Fat & 4.5 & 63.4 & \\
Coarse Fiber & 84.7 & & \\
TDN & & & \\
\hline
\end{tabular}


Table 2

Composition of ingredients in the ransum

\begin{tabular}{lllll}
\hline \multirow{2}{*}{ Composition (\%) } & \multicolumn{3}{c}{ Treatment } \\
\cline { 2 - 5 } & P1 & P2 & P3 & P4 \\
\hline Concentrate & 45 & 30 & 15 & - \\
Gliricidia & - & 15 & 30 & 45 \\
Field Grass & 55 & 55 & 55 & 55 \\
\hline Total & 100 & 100 & 100 & 100 \\
\hline
\end{tabular}

\section{Statistical Analysis}

Data were analyzed by analysis of variance and the differences between treatments were tested by Duncan's multiple area tests (Gaspersz, 1991).

\section{Results and Discussions}

\section{Consumption of nutrients}

The results showed that the average dry matter consumption ranged from 1026.1-1120.4 g/head/day, statistically, the different treatments were not significantly different $(\mathrm{P}>0.05)$. Rostini \& Zakir (2017), get the consumption of dry matter in PE goats ranging from 723.3-745.1 g/head/day. This difference occurs because the animals used have different body weights. This phenomenon indicates that the consumption of dry matter is influenced by the bodyweight of livestock. Supported by the statement of Mathius et al. (2002), livestock body weight significantly influences the consumption of dry matter. Arora (1995), added that livestock body weight is one of the factors that influence the consumption of feed dry matter. The results showed that the average consumption of crude protein ranged from 183.58-207.9 g/head/day, statistically the different treatments were not significantly different $(\mathrm{P}>0.05)$. The highest consumption of crude protein in $\mathrm{P} 2$ treatment is probably caused by the high consumption of dry matter in P2 treatment. Nuraini et al., (2014), states that the increased consumption of crude protein is caused by the consumption of dry matter in the treatment also increases. Purbowati et al. (2003), added that consumption of dry matter and crude protein content in the feed are factors that influence crude protein consumption. Crude fiber consumption of P4 treatment was significantly $(\mathrm{P}<0.05) 33.79 \%$ higher than treatment $\mathrm{P} 1$, but not significantly $(\mathrm{P}>0.05) 20.83 \%$ and $11.6 \%$ higher than treatment P2 and P3. The high consumption of crude fiber in the P4 treatment is probably due to the addition of a high proportion of Gamal leaves by $45 \%$ in the ration where the content of Gamal crude fiber is higher (18.9\%) compared to the concentrate (4.5\%) (Table 1). The higher the percentage of Gamal leaves given in the ration, the higher the consumption of crude fiber. Nevertheless, the high consumption of crude fiber in the form of lignin can reduce digestibility. Crude fat consumption of P1 treatment was not significantly $(\mathrm{P}>0.05)$ higher $7.92 \%$ than $\mathrm{P} 2$ treatment, but significantly $(\mathrm{P}<0.05)$ was $33.22 \%$ and 59\% higher than treatments P3 and P4. If you look at the consumption of crude fat (Table 3) there is a decrease where the lower the percentage of concentrate in the ration, the consumption of crude fat decreases. This is probably due to the higher concentrated crude fat content (15.9\%) compared to Gamal crude fat $(3.3 \%)$ (Table 1) so that the P1 treatment ration with the highest proportion of concentrate shows that the consumption of crude fat has increased, but is not too different from the treatment P2 with the provision of $30 \%$ concentrate plus $15 \%$ Gamal.

\section{Nutrient digestion}

Statistical results showed that the dry matter digestibility coefficient between treatments was not significantly different $(\mathrm{P}>0.05)$ with the average ranging between $66.79-70.34 \%$. Similar results were reported by Maaruf et al. (2014), who obtained the digestibility of dry matter in PE goats ranged from 57.96 to $73.76 \%$. It was

Sofyan, M., Cakra, I. G. L. O., \& Putra, I. G. A. A. (2020). Consumption, nutrient digestibility and nitrogen retention in pe goats received ransum with various levels of gamal (gliricidiasepium) balance versus concentrate. International Journal of Life Sciences, 4(1), 50-57. https://doi.org/10.29332/ijls.v4n1.380 
further explained that the higher the level of concentrate given to goats would also be accompanied by increased digestibility of dry ingredients. If it is seen from the dry matter digestibility coefficient (Table 3) that the treatment which is only given field grass and Gamal is not too different from cattle that get field grass and concentrate. This proves both quantity and quality that the addition of Gamal to the basic grass feed in the field is able to increase the digestibility coefficient caused by increased activity of rumen microbes. The digestibility coefficient of organic matter in this study ranged from 67.64 to $72.32 \%$ and statistically, shows that $\mathrm{P} 1$ is not real $(\mathrm{P}>0.05)$ higher than $4.42 \%$ than $\mathrm{P} 2$, but it is real $(\mathrm{P}<0.05)$ more high respectively $5.67 \%$ and $6.47 \%$ of P3 and P4. The digestibility coefficient of organic matter in P1 treatment (field grass with 45\% concentrate) was not too different from P2 treatment which added a 15\% Gamal but the percentage of concentrate was reduced. This indicates that the addition of a 15\% Gamal can provide economic benefits for farmers. Cakra (2013), explains that organic matter is part of dry matter, so the digestibility of organic material will follow the digestive pattern of dry matter. The crude protein digestibility coefficient in the P1 treatment was not significant $(\mathrm{P}>0.05)$ higher $5.25 \%$ than the $\mathrm{P} 2$ treatment, but it was significantly $(\mathrm{P}<0.05)$ higher $8.98 \%$ and $9.9 \%$ respectively P3 and P4 treatments. This is probably due to the relatively high percentage of P1 treatment rations compared to other treatments. The concentrate in this study contained urea as a source of nitrogen for rumen microbes and the presence of molasis as a provider of soluble carbohydrates and energy. Urea is a food material that is easily hydrolyzed so it has a high solubility in the rumen. Siti et al. (2013), explain that the addition of urea molasis block (UMB) in the Gamal forage can increase the digestibility coefficient of crude protein. Therefore the concentrate containing urea in this study was able to increase the activity of rumen microbes in digesting feed. When seen in the crude protein digestibility coefficient P2 treatment given 15\% Gamal and 30\% concentrate, not too different from the P1 treatment which was only given $45 \%$ concentrate. This shows that the digestibility of Gamal crude protein is quite optimal because of the availability of NPN (non-protein nitrogen) as a source of nitrogen for microbes and easily degraded in the rumen. The digestibility coefficient of crude fiber between treatments was not significantly different $(\mathrm{P}>0.05)$ and the highest mean was in treatment $\mathrm{P} 4$ of $49.67 \%$. This is probably caused by the high consumption of crude fiber and crude fiber content is Gamal. Despal (2000), explains that low crude fiber content will increase the digestibility of ration and vice versa. This indicates that crude fiber is negatively related to digestibility. Coefficient fat digest coefficient of treatment P2, P3 and P4 lower respectively $8.88 \%, 18.52 \%$ and $38.15 \%$ of the treatment $\mathrm{P} 1$ treatment, but statistically significantly different $(\mathrm{P}<0.05)$. In the treatment of $\mathrm{P} 1$, the highest coefficient of crude fat digestibility is due to the high content of crude fat and the consumption of crude fat in P1 treatment.

Table 3

Analysis Results Statistics consumption, nutrient digestibility and nitrogen retention

\begin{tabular}{|c|c|c|c|c|c|}
\hline \multirow{2}{*}{ Variable } & \multicolumn{4}{|c|}{ Treatment (1) } & \multirow{2}{*}{ SEM (2) } \\
\hline & P1 & $\mathrm{P} 2$ & P3 & $\mathrm{P} 4$ & \\
\hline \multicolumn{6}{|l|}{ Nutrition consumption } \\
\hline - Dry ingredients (g/head/day) & $1026.10^{\mathrm{a}(3)}$ & $1120.40^{\mathrm{a}}$ & $1087.80^{\mathrm{a}}$ & $1060.40^{\mathrm{a}}$ & 105.25 \\
\hline - Crude protein (g/head/day) & $188.00^{\mathrm{a}}$ & $207.90^{\mathrm{a}}$ & $197.73^{a}$ & $183.58^{\mathrm{a}}$ & 18.47 \\
\hline - Coarse Fiber (g/head/day) & $152.65^{b}$ & $182.53^{\mathrm{ab}}$ & $203.80^{\mathrm{ab}}$ & $230.55^{\mathrm{a}}$ & 13.23 \\
\hline - Coarse Fat (g/head/day) & $107.33^{\mathrm{a}}$ & $98.83^{a}$ & $71.68^{\mathrm{b}}$ & $44.00^{c}$ & 10.28 \\
\hline \multicolumn{6}{|l|}{ Digestive Digestion Nutrients } \\
\hline - Dry ingredients (\%) & $70.34^{\mathrm{a}}$ & $67.18^{a}$ & $67.02^{\mathrm{a}}$ & $66.79^{a}$ & 2.11 \\
\hline - Organic matter (\%) & $72.32^{\mathrm{a}}$ & $69.12^{\mathrm{a}}$ & $68.22^{\mathrm{b}}$ & $67.64^{\mathrm{b}}$ & 1.83 \\
\hline - Crude protein (\%) & $81.75^{\mathrm{a}}$ & $77.46^{\mathrm{ab}}$ & $74.41^{\mathrm{b}}$ & $73.66^{b}$ & 1.49 \\
\hline - Coarse Fiber (\%) & $41.91^{\mathrm{a}}$ & $41.57^{\mathrm{a}}$ & $48.08^{a}$ & $49.67^{\mathrm{a}}$ & 2.26 \\
\hline - Coarse Fat $(\%)$ & $83.89^{a}$ & $76.44^{\mathrm{b}}$ & $68.35^{c}$ & $51.89^{d}$ & 2.13 \\
\hline \multicolumn{6}{|l|}{ Retention } \\
\hline - Consumption N (g/head/day) & $30.08^{a}$ & $33.27^{a}$ & $31.64^{\mathrm{a}}$ & $29.37^{a}$ & 2.96 \\
\hline - N Feces (g/head/day) & $5.45^{b}$ & $7.54^{\mathrm{ab}}$ & $8.35^{\mathrm{a}}$ & $7.64^{\mathrm{ab}}$ & 0.41 \\
\hline - N Urine (g/head/day) & $6.63^{b}$ & $10.25^{\mathrm{ab}}$ & $16.22^{\mathrm{a}}$ & $15.06^{\mathrm{a}}$ & 2.14 \\
\hline - Nitrogen retention(g/head/day) & $18.01^{\mathrm{a}}$ & $15.47^{a}$ & $7.07 \mathrm{~b}$ & $6.67^{\mathrm{b}}$ & 1.39 \\
\hline
\end{tabular}

Note: 
1) P1 (55\% field grass with 45\% concentrate); P2 (55\% field grass with 15\% gamal and 30\% concentrate); P3 (55\% field grass with 30\% gamal and 15\% concentrate); P4 (55\% field grass with 45\% gamal.

2) SEM: Standard Error of Treatment Means

3) Values with different letters on the same line show significant differences $(\mathrm{P}<0.05)$.

\section{Nitrogen retention}

Consumption $\mathrm{N}$ between treatments was not significantly different $(\mathrm{P}>0.05)$ with the highest average in treatment, P2 was $33.27 \mathrm{~g} /$ head/day. The high consumption $\mathrm{N}$ of P2 treatment is caused by high consumption of crude protein which can be interpreted as increasing consumption of N (Suryani \& Arya, 2017). Tillman et al. (1991), explain that the increase in crude protein consumption is in line with the increase in consumption $\mathrm{N}$, because one of the constituent elements of crude protein is the $\mathrm{N}$ element. $\mathrm{N}$ feces of P3 treatment was not significantly ( $\mathrm{P}>0.05$ ) higher, respectively $9.7 \%$ and $8.5 \%$ than treatments $\mathrm{P} 2$ and $\mathrm{P} 4$, but significantly ( $\mathrm{P}$ $<0.05$ ) $34.73 \%$ higher than treatment P1. Van Soest (1994), explains that the efficient use of $N$ in the rumen, as well as digestible $\mathrm{N}$, will affect the levels of $\mathrm{N}$ in the stool. $\mathrm{N}$ stools that come out in small amounts indicate the increase in N digested. According to Pond et al. (1995), that the process and type of digestive tract, as well as the type of food consumed, are things that affect $\mathrm{N}$ expenditure through feces. N Urine of P3 treatment was not significantly $(\mathrm{P}>0.05)$ higher by $36.8 \%$ and $7.15 \%$ of treatments $\mathrm{P} 2$ and $\mathrm{P} 4$, however significant $(\mathrm{P}<0.05)$ was $59.12 \%$ higher than treatment P1. There was no apparent difference in N urine of goat PE in treatments P2, P3 and P4, indicating the overall metabolic rate of goats. This is in accordance with the opinion of Putra (2006), that $\mathrm{N}$ urine can be expressed as a result of protein diets that are not metabolized. This is supported by Tillman et al. (1991), that largely untapped nitrogen is excreted in the form of urea filtered by the kidneys. The high $\mathrm{N}$ urine in the P4 and P3 treatments is due to the low consumption N in the P4 and P3 treatments, the lower the $\mathrm{N}$ consumed, the $\mathrm{N}$ levels in the urine increase. $\mathrm{N}$ retention is calculated based on the nitrogen consumed minus urine nitrogen and fecal nitrogen. The results showed that nitrogen retention (RN) in this study ranged from $6.67-18.01 \mathrm{~g} / \mathrm{head} /$ day. The $\mathrm{N}$ retention of the $\mathrm{P} 1$ treatment was not significantly $(\mathrm{P}>0.05)$ $14.1 \%$ higher than the $\mathrm{P} 2$ treatment, but it was significantly $(\mathrm{P}<0.05)$ higher respectively $60.74 \%$ and $62.97 \%$ than the P3 treatment and Q4. N retention in P2 treatment decreased RN value $(15.47 \mathrm{~g} / \mathrm{head} /$ day $)$ but not too different from P1 treatment. Siti et al. (2013), reported the highest nitrogen retention value in PE goats of $5.02 \mathrm{~g} /$ head/day fed ad libitum field grass and supplementation of $225 \mathrm{~g}$ rice bran. This happens because of the increased digestibility of dry matter and crude protein caused by increased microbial activity and population in the presence of rice bran in concentrates as a provider of soluble carbohydrates. Concentrates contain high protein and high protein digestibility value (Yadnya et al., 2016; Nuriyasa et al., 2018). It was proven that the digestibility of crude protein in the highest P1 treatment was $81.75 \%$, so the nitrogen retention value in the P1 treatment was also the highest, but not too different from the nitrogen retention in the P2 treatment. This indicates that the balance of 30\% concentrate with $15 \%$ Gamal get a fairly high nitrogen retention value.

\section{Conclusion}

The conclusion of this research is the provision of P2 treatment feed with a balance of $30 \%$ concentrate and $15 \%$ Gamal on the grass base feed can increase consumption, nutrient digestibility and nitrogen retention in PE goats and very efficiently provide economic benefits for farmers.

\section{Acknowledgments}

We are grateful to two anonymous reviewers for their valuable comments on the earlier version of this paper.

Sofyan, M., Cakra, I. G. L. O., \& Putra, I. G. A. A. (2020). Consumption, nutrient digestibility and nitrogen retention in pe goats received ransum with various levels of gamal (gliricidiasepium) balance versus concentrate. International Journal of Life Sciences, 4(1), 50-57. https://doi.org/10.29332/ijls.v4n1.380 


\section{References}

Arora, S. P. (1995). Pencernaan Mikroba Pada Ruminansia. Diterjemahkan Oleh: Retno Murwani.

Budisatria, I. G. S., \& Agus, A. (2014). Pengaruh tingkat penggunaan pakan penguat terhadap performa induk kambing Bligon di peternak rakyat. Buletin Peternakan, 38(1), 34-41. https://doi.org/10.21059/buletinpeternak.v38i1.4614

Cakra, I.G.L.O. (2013). "Peranan Urea KapurdalamKonsentrat yang Mengandung Ubi Kayu Terhadap Kinerja Rumen dan Pertumbuhan Kambing Peranakan Etawah" (disertasi). Denpasar: Universitas Udayana.

Despal, D. (2000). Kemampuan Komposisi Kimia dan Kecernaan In Vitro dalam Mengestimasi Kecernaan In Vivo. Media Peternakan, 23(3), 84-88.

Gaspersz, V. (1991). Metode perancangan percobaan. Armico. Bandung, 384.

Hartadi, H., Reksohadiprodjo, S., Lebdosukojo, S., \& Tillman, A. D. (1980). Tabel Komposisi Bahan Makanan Ternak Untuk Indonesia. Fakultas Peternakan Universitas Gadjah Mada Program EFD, Yogyakarta.

Jalaludin. 1994. Uji Banding Gamal dan Angsana sebagai Agensia Defaunasi dan Suplementasi Analog Metionindan Ammonium Sulfat dalam Ransum Pertumbuhan Sapi PerahJantan. (tesis). Pascasarjana, Institut Pertanian Bogor. Bogor.

Kearl, L. C. (1982). Nutrient requirements of ruminants in developing countries. International Feedstuffs Institute.

Maaruf, K., Waani, M. R., \& Pontoh, C. J. (2014). Pengaruh penggunaan konsentrat dalam pakan rumput benggala (Panicum maximum) terhadap kecernaan bahan kering dan bahan organik pada kambing lokal. ZOOTEC, 34, 108-114.

Mathius, I., Sastradipradja, D., Sutardi, T., Natasasmita, A., Sofyan, L., \& Sihombing, D. (2002). Studi strategi kebutuhan energi-protein untuk domba lokal: 4. Domba induk fase bunting tua. JITV, 7(3), 167-180.

Nuriyasa, I. M., Puspani, E., \& Yupardhi, W. S. (2018). Performance and carcass of local rabbit (Lepus nigricollis) fed concentrate on different levels based on carrot leaf waste (Daucus carota L.). International Journal of Life Sciences, 2(3), 13-19. https://doi.org/10.29332/ijls.v2n3.189

Pond, W. G., Church, D. B., Pond, K. R., \& Schoknecht, P. A. (2004). Basic animal nutrition and feeding. John Wiley \& Sons.

Purbowati, E., Baliarti, E., \& Budhi, S. P. S. (2003). Kondisi cairan rumen domba yang digemukkan secara feedlot dengan pakan dasar dan aras konsentrat berbeda. J. Indon. Anim. Agric, 28(3), 134-140.

Putra, S. (2006). Perbaikan mutu pakan yang disuplementasi seng asetat dalam upaya meningkatkan populasi bakteri dan protein mikroba di dalam rumen, kecernaan bahan kering, dan nutrien ransum sapi Bali bunting. Majalah Ilmiah Peternakan, 9(1).

Rostini, T., \& Irwan, Z. (2017). Performans Produksi, Jumlah Nematoda Usus, dan Profil Metabolik Darah Kambing yang Diberi Pakan Hijauan Rawa Kalimantan. Jurnal Vet, 18(3), 469-477. https://doi.org/10.19087/jveteriner.2017.18.3.469

Siti, N. W., Witariadi, N. M., Mardewi, N. K., Mudita, I. M., Roni, N., Cakra, I. G., \& Sukmawati, N. S. (2013). Utilisasi Nitrogen dan Komposisi Tubuh Kambing Peranakan Etawah yang diberi Pakan Hijauan Rumput Lapangan dengan Suplementasi Dedak Padi. Majalah Ilmiah Peternakan. https://doi.org/10.24843/MIP.2013.v16.i01.p04

Soest, V. (1994). PJ 1994. Nutritional ecology of the ruminant. Van Soest PJ (2nd ed.). Fiber and Physicochemical Properties of Feeds. Corneell University Press, Ithaca and London, 140-155.

Suarna, M., Sukanten, I., Puma, S., Lana, K., \& Nitis, I. M. (1994). Effect of cutting height on the growth of Glirisidia sepium provenances grown under alley cropping system. In Proc. 7th MAP. Animal congress. Bali. ISPI (pp. 505-506).

Suryani, S. A. M. P., \& Arya, I. W. (2017). Improving the quality of tilapia (oreochromis niloticus) with consumption measures leaf extract neem (azadirachta indica a. juss) as antiparasitic. International Journal of Life Sciences, 1(3), 28-37. https://doi.org/10.21744/ijls.v1i3.62

Tillman, A. D., Hartadi, H., \& Reksohadiprodjo, S. S. Prawirokusumo dan S. Lebdosoekojo. (1991). Ilmu Makanan Ternak Dasar.

Yadnya, T. B., Trisnadewi, A. A., Sukada, I. K., \& Oka, I. G. L. (2016). The effect of fermented purple sweet potato (ipomoea batatas l) skin in diets on feed and anthocyanin consumption, carcass characteristics, anthioxidant profile and meat texture of Bali duck. International Research Journal of Engineering, IT \& Scientific Research, 2(9), 73-80. 


\section{Biography of Authors}

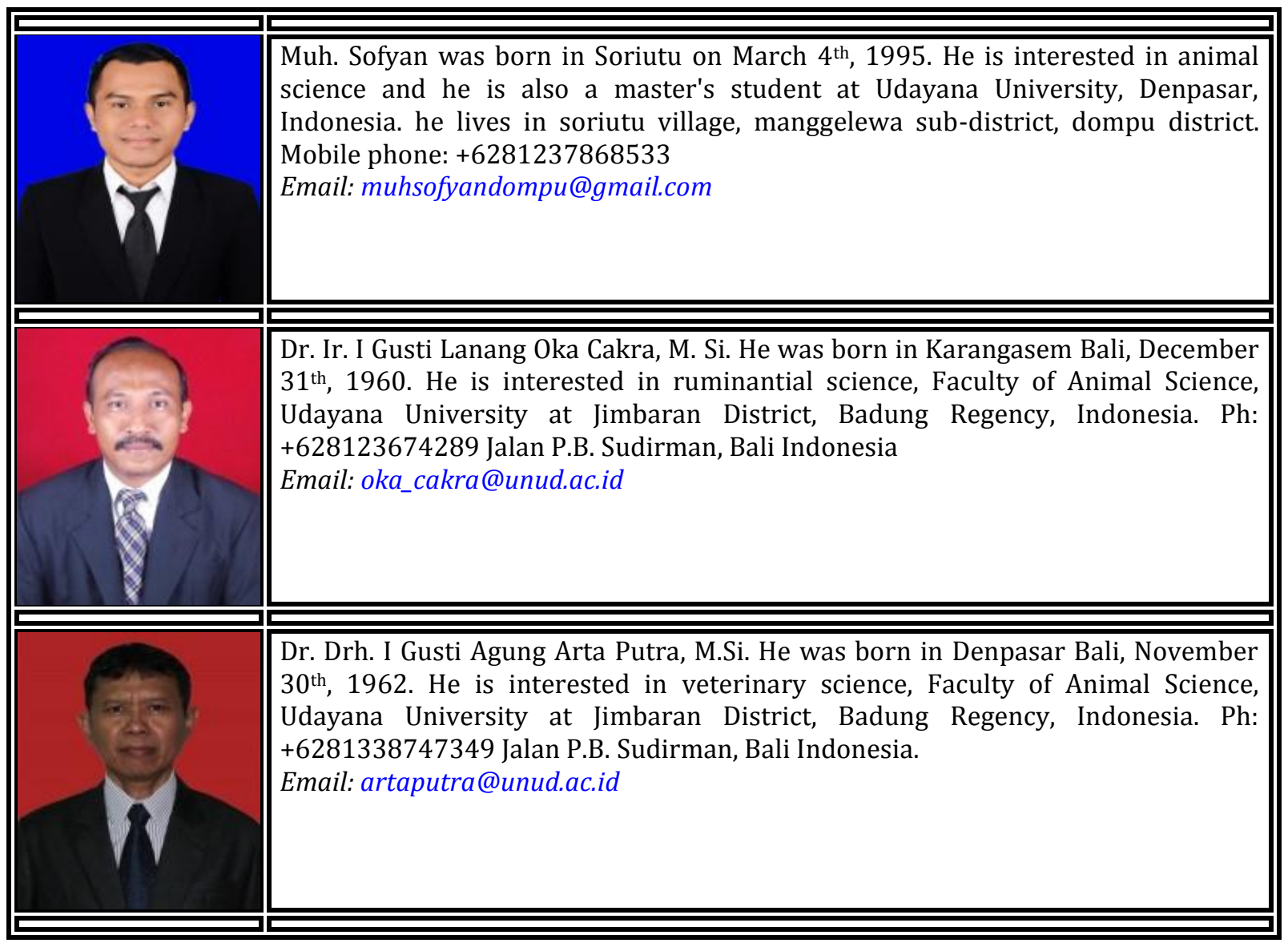

Sofyan, M., Cakra, I. G. L. O., \& Putra, I. G. A. A. (2020). Consumption, nutrient digestibility and nitrogen retention in pe goats received ransum with various levels of gamal (gliricidiasepium) balance versus concentrate. International Journal of Life Sciences, 4(1), 50-57. https://doi.org/10.29332/ijls.v4n1.380 